\title{
Enhanced energy status of corals on coastal, high-turbidity reefs
}

\author{
Kenneth R. N. Anthony* \\ Centre for Coral Reef Biodiversity, School of Marine Biology and Aquaculture, James Cook University, Townsville, \\ Queensland 4811, Australia
}

Present address: Centre for Marine Studies, University of Queensland, St. Lucia, Queensland 4072, Australia

\begin{abstract}
Sedimentation and high turbidity have long been considered a major threat to corals, causing world-wide concern for the health of coral reefs in coastal environments. While studies have demonstrated that sediment conditions characteristic of inshore reefs cause stress in corals, the consequences of such conditions for the physiological status of corals require testing in field situations. Here, I compare the size of energy stores (as lipid content), a proxy for physiological condition, of 2 coral species (Turbinaria mesenterina and Acropora valida) between coastal and offshore environments. Corals on coastal reefs contained 4 -fold ( $T$. mesenterina) and 2 -fold (A. valida) more lipid than conspecifics offshore, despite 1 order of magnitude higher turbidity levels inshore. Results were consistent across 4 sites in each environment. Reproductive investment in A. valida (a seasonal mass spawner) did not vary between environments, suggesting that the larger lipid stores in corals on coastal reefs are mainly somatic energy reserves. These results demonstrate that the environmental conditions on inshore, high-turbidity reefs do not always impact negatively on the physiology of corals. The contrasting lipid levels of $T$. mesenterina between environments may explain its greater success on coastal reefs.
\end{abstract}

KEY WORDS: Turbidity $\cdot$ Sedimentation $\cdot$ Energy storage $\cdot$ Lipid $\cdot$ Scleractinian coral

\section{INTRODUCTION}

Reports of increasing sediment and nutrient delivery from terrestrial run-off to coral reefs in coastal environments have caused growing concern world-wide (Brown 1997, Bryant et al. 1998, Wilkinson 2002). On Australia's Great Barrier Reef, in particular, sediment delivery to coastal waters has increased 5- to 10-fold during the past century (McCulloch et al. 2003). Under predicted climate-change scenarios, where flooding and consequent land run-off become more frequent and severe (IPCC 2001), sediment stresses on coral reefs are expected to increase globally (Hughes et al. 2003). This concern is based partly on the common belief that clear oceanic water provides optimal growth conditions for reef corals. Sediment and other particles suspended in the water (turbidity) may smother coral tissues (Rogers 1990) and reduce the penetration of light, which is a key resource for reef- building corals (Muscatine 1990). However, corals occur naturally in a wide range of habitats, including coastal environments characterised by extreme turbidity levels and high rates of sedimentation (Anthony et al. 2004), lower flow rates (Done 1982) and higher temperatures (Berkelmans 2002). Importantly, in addition to photosynthesis, corals also acquire energy and nutrients by feeding on a wide range of particle types, including sediment (Anthony 1999, Rosenfeld et al. 1999). Coastal waters are often rich in organic nutrients, bound up in the planktonic organisms (Furnas et al. 2005) and suspended particulate matter (Roman et al. 1990, Anthony 1999), potentially providing a rich heterotrophic environment for corals. In contrast, coral growth rates in clear oceanic conditions may be limited by the availability of nutrients in dissolved or particulate form (e.g. Dubinsky \& Jokiel 1994, Anthony et al. 2002, Houlbrèque et al. 2005). The physical and trophic environment of coastal reefs, therefore, differs 
from that of offshore reefs, but may not be less favourable for the physiology of some coral species. Here, I test this hypothesis by comparing the size of energy stores between corals of 2 common species (Turbinaria mesenterina and Acropora valida) at 4 inshore and 4 offshore sites in Australia's Great Barrier Reef lagoon. Energy storage, here approximated by total lipid stores, is an important indicator of physiological condition (e.g. Maltby 1999, Nisbet et al. 2000). Although protein and carbohydrates also vary with environmental conditions (Anthony \& Fabricius 2000), they contain only half the energy content per unit weight (Gnaiger \& Bitterlich 1984). As lipid stores can be allocated to both growth and reproduction, their size provides a physiological proxy for fitness.

\section{MATERIALS AND METHODS}

Study species. To represent coral species that occur commonly in coastal and offshore environments in the

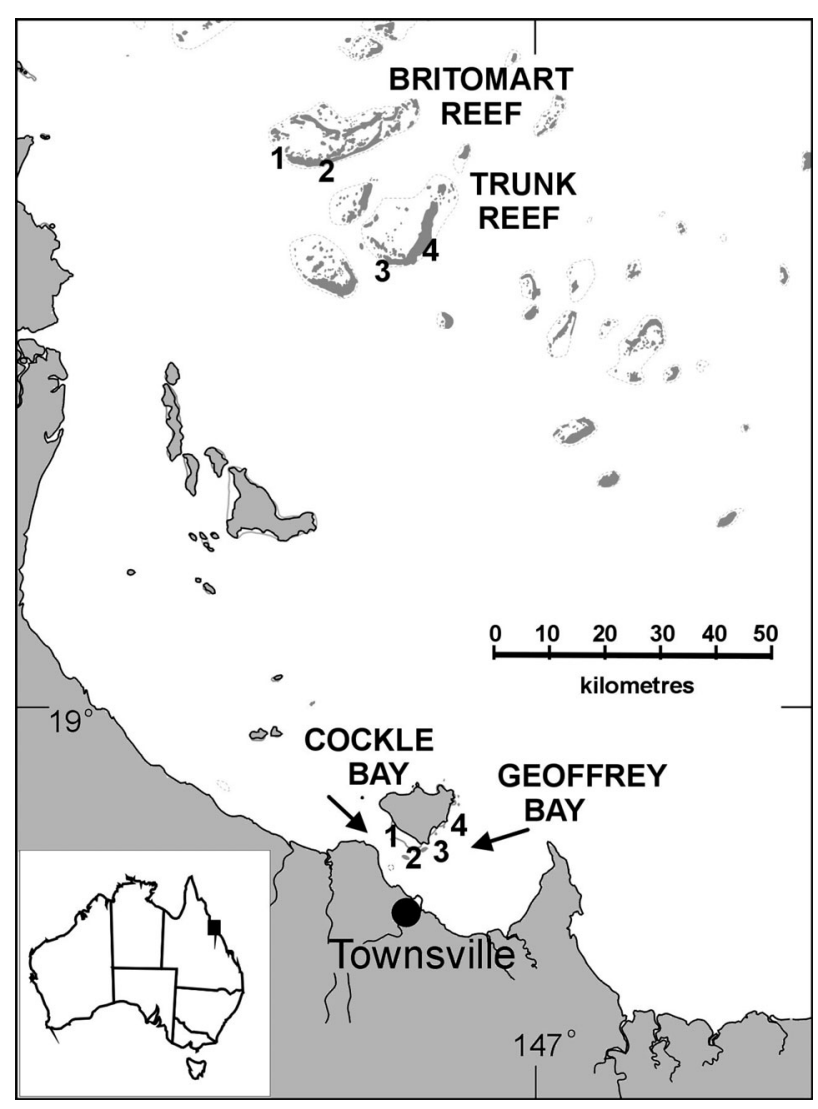

Fig. 1. Central section of the Great Barrier Reef, showing the locations of the 4 coastal and 4 offshore (midshelf) sites; 10 to 15 colonies of 2 coral species (Turbinaria mesenterina and Acropora valida) were sampled at each site for lipid contents (as a proxy for physiological condition)
Great Barrier Reef (GBR) lagoon, Acropora valida and Turbinaria mesenterina were used as study species. The genus Acropora is wide-spread and represents nearly $70 \%$ of the coral diversity in the Indo-Pacific, and is the dominant taxon on offshore reefs of the GBR (Done 1982). The genus Turbinaria is also widespread, but often dominates on reefs in turbid water (Veron 1986). A. valida releases its gametes in a single broadcast-spawning event, which enables estimates of reproductive output. T. mesenterina does not have a distinct spawning period, but reaches maximum fecundity in the Austral summer and releases gametes throughout the season.

Study sites. Four coastal sites were selected on 2 fringing reefs (Cockle and Geoffrey Bays), 10 to $20 \mathrm{~km}$ from the coast of north Queensland (Townsville, Australia), and 4 sites on midshelf reefs (Britomart and Trunk Reefs), in the central GBR lagoon, $>50 \mathrm{~km}$ offshore (Fig. 1). Long-term (2 to $4 \mathrm{mo}$ ) records of downwelling underwater and surface irradiance were obtained at 2 coastal and 2 offshore logger stations with cosine-corrected PAR (photosynthetically active radiation) sensors (Dataflow Systems), positioned at the surface and on the bottom (Table 1). All sensors were fitted with custom-made automatic wipers to prevent biofouling. Turbidity was estimated based on the attenuation of irradiance between the surface and bottom sensors (parameter $k_{\mathrm{D}}$ ) using a modified version of Lambert-Beers law (Anthony \& Fabricius 2000), and assuming a homogenous distribution of particles in the water column (Anthony et al. 2004). Water temperatures averaged $26^{\circ} \mathrm{C}$ at the inshore and $25^{\circ} \mathrm{C}$ at the midshelf sites during the second half of 2001, reaching maximum temperatures inshore of $29.3^{\circ} \mathrm{C}$ prior to spawning in November and midshelf of $28^{\circ} \mathrm{C}$. No corals were observed to undergo bleaching during this period.

Coral sampling and analysis. Collection of coral samples for total lipids was conducted during the period from October to December 2001, 1 to 2 wk before and after the spawning time for most corals on the GBR (Harrison et al. 1984). Pre-spawning lipid contents represent the annual maximum of both species, and the difference in lipid content between sampling occasions provides an estimate of reproductive output (Leuzinger et al. 2003) for the synchronous spawner Acropora valida. At each site and on each sampling occasion, duplicate fragments (5 cm long) were sampled from the central sections of 6 to 20 coral colonies, frozen at $-70^{\circ} \mathrm{C}$ and later analysed for lipids. At a given site, a similar number of fragments were collected on each sampling occasion. Only large (20 to $110 \mathrm{~cm}$ diameter) coral colonies were used to minimise effects of repetitive sampling (Babcock 1991). The latter was validated by linear regression analyses, showing a 
Table 1. Summary data for downwelling benthic photosynthetic irradiance (PAR) and light attenuation coefficients ( $k_{\mathrm{D}}$, proxy for turbidity) at 2 coastal and 2 offshore coral sampling sites in the Great Barrier Reef lagoon. Irradiances are means of hourly integrated readings from sunrise to dawn. Light attenuation was estimated based on the difference in irradiance between surface and bottom loggers (2 to $5 \mathrm{~m}$ water depth, see 'Materials and methods; Study sites' for details). Numbers in parentheses: standard deviations; $\mathrm{N}$ : number of days that the loggers were deployed

\begin{tabular}{|lcccr|}
\hline $\begin{array}{l}\text { Environ- } \\
\text { ment }\end{array}$ & Site & $\begin{array}{c}\text { Mean irradiance } \\
\text { at sampling depth } \\
\left(\mu \mathrm{mol} \text { photons } \mathrm{m}^{-2} \mathrm{~s}^{-1}\right)\end{array}$ & $\begin{array}{c}\text { Light attenuation } \\
\left(k_{\mathrm{D}}, \mathrm{m}^{-1}\right)\end{array}$ & $\begin{array}{c}\mathrm{N} \\
(\mathrm{d})\end{array}$ \\
\hline Coastal & 1 & $279(92)$ & $0.452(0.140)$ & 164 \\
& 3 & $172(67)$ & $0.284(0.088)$ & 119 \\
Offshore & 1 & $1040(249)$ & $0.048(0.024)$ & 60 \\
& 3 & $1117(152)$ & $0.024(0.020)$ & 50 \\
\hline
\end{tabular}

non-significant relationship between lipid content and colony size for both species and environments. Each frozen sample was ground to a paste, and total lipid was extracted using a standard procedure (Leuzinger et al. 2003). Briefly, the lipid was extracted in chloroform-methanol $(2: 1 \mathrm{v} / \mathrm{v})$, filtered and washed in $0.88 \%$ $\mathrm{KCl}$ and methanol- $\mathrm{H}_{2} \mathrm{O}(1: 1 \mathrm{v} / \mathrm{v})$, and the liquid was evaporated. To facilitate comparison between species, lipid data should ideally be normalised to surface area as well as biomass (Edmunds \& Gates 2002). However, because the focus of this study was to compare lipid stores among environments and sites within each species, data were standardised to skeletal surface area only (Marsh 1970).

Data analysis. The effect of environment on lipid content before spawning was analysed separately for each species, using a 2-way nested analysis of variance (ANOVA), in which sites were nested within environment. A multiple comparisons test (Tukey's) was used to distinguish groups that differed significantly. Data for Turbinaria mesenterina were square-root transformed to meet the assumptions of ANOVA. The effect of environment on the absolute and relative losses of total lipids during spawning in Acropora valida was tested using similar analyses.

\section{RESULTS}

Turbidity levels as estimated by light attenuation $\left(k_{\mathrm{D}}\right)$ were 6 to 20 times higher at the coastal sites $(0.284$ to $0.452 \mathrm{~m}^{-1}$ ) compared to at the offshore sites (0.024 to $0.048 \mathrm{~m}^{-1}$; Table 1). Consequently, average daily irradiances for corals at the coastal sites (170 to $280 \mu \mathrm{mol}$ photons $\mathrm{m}^{-2} \mathrm{~s}^{-1}$ ) were only 15 to $30 \%$ of those at the offshore sites (1000 to $1100 \mu \mathrm{mol}$ photons $\mathrm{m}^{-2} \mathrm{~s}^{-1}$ ) at similar depths (2 to $5 \mathrm{~m}$; Table 1 ). Irradiances were highly vari- able at the coastal sites, mainly due to periodic sediment resuspension by waves (Anthony et al. 2004). During extended periods (weeks), light levels fell below $5 \%$ of those at the offshore sites.

Contents of total lipids within tissues of Turbinaria mesenterina and Acropora valida were 4 - and 2-fold larger at the coastal sites compared to the offshore sites, respectively. This pattern was consistent across the 4 sites in each environment for both species (Fig. 2, Table 2). There was no effect of site for $T$. mesenterina, but 1 inshore site (Geoffrey Bay, Site 2) showed significantly higher lipid levels for $A$. valida. This was potentially due to the fact that corals here were sampled in slightly shallower water (i.e. higher light and/or flow regime). Variation in lipid content within and among sites within environments was surprisingly low. Specifically, coefficients of variation within sites ranged from only 4 to $17 \%$ in $T$. mesenterina and 4 to $13 \%$ in A. valida.

Absolute loss of lipids during spawning (representing reproductive output) in Acropora valida did not differ significantly between the coastal and offshore sites (Table 3, Fig. 3A). However, lipid losses relative to

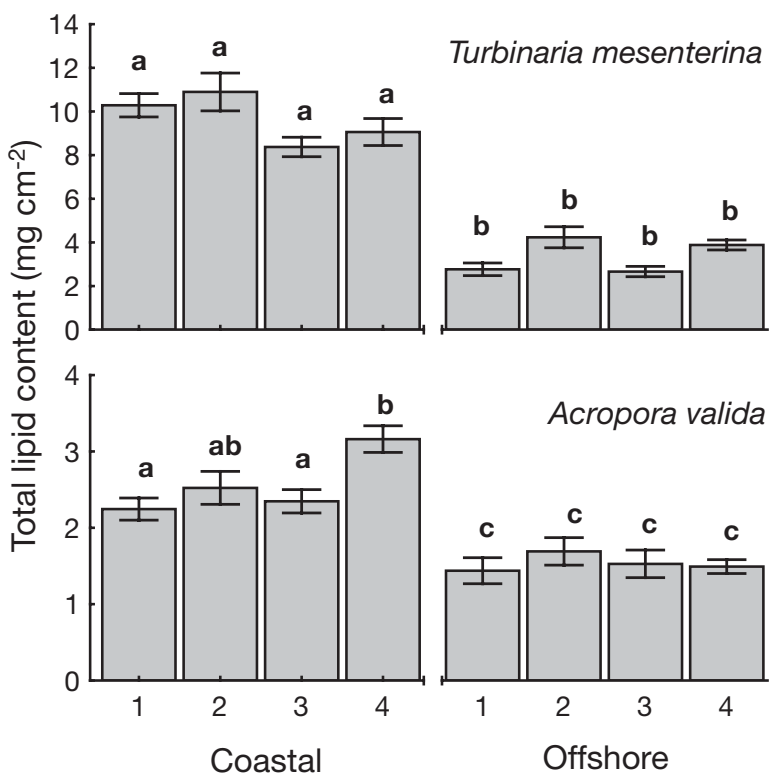

Fig. 2. Turbinaria mesenterina, Acropora valida. Total lipid content of coral samples collected 1 wk prior to the spawning event on the Great Barrier Reef lagoon in 2001 (October on inshore and November/December on offshore reefs). Data are means \pm standard errors of $\mathrm{N}=10$ to 15 colonies per site. Results of a 2-factor nested ANOVA for effects of environment (inshore vs. offshore) and site on total lipid content for each species indicated strong effects $(p<0.001)$ of environment in both species, and some variation among the coastal sites $(p=0.013)$ in Acropora valida. Groups that share the same letters are not significantly different by the multiple comparisons test 
Table 2. Acropora valida, Turbinaria mesenterina. Summary results of 2-way nested ANOVA for effects of environment (inshore vs. offshore position) and site on tissue lipid content in 2 coral species prior to the spawning event in October to November 2001. To meet ANOVA assumptions (normality and variance homogeneity), data for $T$. mesenterina were square-root transformed. Significant values in bold

\begin{tabular}{|lrrrr|}
\hline Source of variation & df & MS & \multicolumn{1}{c|}{$F$} & \multicolumn{1}{c|}{ p } \\
\hline A. valida & & & & \\
Environment & 1 & 15.03 & 13.3 & $<\mathbf{0 . 0 0 1}$ \\
Site (Environment) & 6 & 1.37 & 2.8 & $\mathbf{0 . 0 1 3}$ \\
Error & 102 & 0.48 & & \\
T. mesenterina & & & & \\
$\quad$ Environment & 1 & 38.67 & 136.16 & $<\mathbf{0 . 0 0 1}$ \\
Site (Environment) & 6 & 0.52 & 1.8 & 0.142 \\
Error & 150 & 0.28 & & \\
& & & & \\
\hline
\end{tabular}

Table 3. Acropora valida. Results of 2-way nested ANOVA for effects of environment (inshore vs. offshore position) and site on lipid loss during the spawning event in October/November (inshore) and November/December (offshore) in 2001. Untransformed data met ANOVA assumptions of normality (Kolmogorov-Smirnov test, $\mathrm{p}>0.20$ ) and variance homogeneity (Levene's test, absolute loss: $F_{[7,72]}=0.390, \mathrm{p}=0.905$; relative loss: $\left.F_{[7,72]}=1.15, \mathrm{p}=0.341\right)$. Significant values in bold

\begin{tabular}{|lrccc|}
\hline Source of variation & df & MS & $F$ & $\mathrm{p}$ \\
\hline Absolute loss & & & & \\
Environment & 1 & 0.188 & 0.63 & 0.429 \\
Site (Environment) & 6 & 0.293 & 0.99 & 0.439 \\
Error & 70 & 0.296 & & \\
Relative loss & & & & \\
Environment & 1 & 6447 & 16.85 & $<\mathbf{0 . 0 0 1}$ \\
Site (Environment) & 6 & 431 & 1.603 & 0.356 \\
Error & 70 & 382 & & \\
\hline
\end{tabular}

lipid stores prior to spawning (representing relative reproductive output) were 50 to $100 \%$ greater at the offshore sites (Fig. 3B). The difference in relative lipid loss between environments was mainly driven by the 2-fold greater losses at 1 offshore site (Britomart Reef, Site 1). The non-significant difference in lipid loss between environments suggests 2 points. Firstly, larger lipid stores of $A$. valida at coastal sites prior to spawning (Fig. 2) were likely to be made up of predominantly structural lipids, representing somatic energy reserves. Secondly, a relatively larger proportion of the smaller lipid stores in corals on offshore sites may be invested into reproduction. Lipid losses of $A$. valida during spawning were associated with 2- to 3-fold greater error than pre-spawning lipid stores (Fig. 3), which was, in part, explained by a small fraction of the sample population at each site (10 to $20 \%)$ maintaining constant lipid levels (i.e. not undergoing spawning).
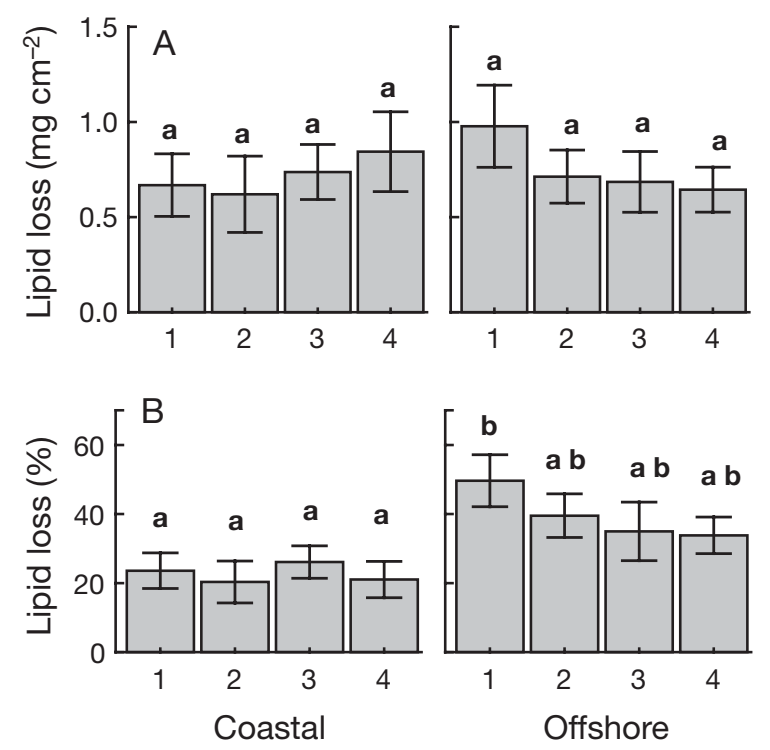

Fig. 3. Acropora valida. (A) Absolute and (B) relative (percentage) loss of total lipids (representing reproductive output) in A. valida during a 2 wk period encompassing its spawning event. Data are means \pm standard errors of $N=6$ to 12 samples per site. The 2-factor nested ANOVA for effects of environment and site on lipid loss showed strong effects $(\mathrm{p}<$ 0.001 ) for relative losses of lipid only. The same letters above bars indicate groups that are not significantly different by the multiple comparisons test

\section{DISCUSSION}

The 4-fold higher lipid contents of Turbinaria mesenterina and 2-fold higher lipid contents of Acropora valida at the 4 inshore sites demonstrate that conditions on coastal reefs do not incur greater physiological stress in corals than on offshore reefs. Also, the low variation in reproductive investment, which is a key indicator of fitness and physiological condition (e.g. Harrison \& Wallace 1990, Maltby 1999, Nisbet et al. 2000) across turbidity regimes in A. valida, suggests that the coral physiology is more robust to high turbidity than previously assumed. In addition to high turbidities (light attenuations), inshore reefs are also subject to higher temperatures (Berkelmans 2002) and lower flow regimes (e.g. Done 1982), factors that may both contribute to reduced coral energy states. For example, low flow velocities limit rates of photosynthesis (Patterson et al. 1991) and food delivery (Sebens et al. 1998). The role of temperature on energetics is complex, in that high temperature may promote anabolic processes (growth), but may also induce bleaching, which leads to reduced energy status (e.g. Grottoli et al. 2004).

The most plausible explanation for the higher lipid stores in both coral species at the coastal sites is higher 
rates of particle feeding, leading to reduced nutrient limitation on tissue growth. Numerous coral species, including members of Acropora, feed on suspended particles in near-proportion to availability (Anthony 1999), leading to at least an order of magnitude higher rates of particle (and nutrient) intake on coastal reefs (Anthony 2000). Under more oligotrophic conditions such as those characteristic of many offshore reefs, rates of tissue growth may be nutrient limited, because carbon fixation greatly exceeds the supply of macronutrients (e.g. $\mathrm{N}$ and $\mathrm{P}$ ) needed for the synthesis of protein and structural lipids (Crossland 1987).

Alternatively, lower rates of linear extension (skeletal growth) on inshore reefs could lead to a greater build-up of lipid per unit tissue surface area. However, this would require much higher rates of extension in offshore corals, which is contrary to reported observations (Barnes \& Lough 1999, Anthony et al. 2002). For example, Barnes \& Lough (1999) found that linear extension rates in Porites were unaffected across a wide range of sediment regimes. Similarly, Anthony \& Fabricius (2000) found that tissue growth rates in Porites cylindrica and Goniastrea retiformis nearly doubled under turbidity loads of 4 to 8 and $16 \mathrm{mg} \mathrm{l}^{-1}$, respectively, whereas rates of calcification showed minor variation across turbidity regimes. Also, because the energy cost of skeletal growth in plating and branching morphologies is only a tenth of the cost of tissue growth (Anthony et al. 2002), reduced rates of calcification would represent only a small amount of energy available for lipid storage.

A functional and adaptive significance of large lipid stores in corals on coastal reefs is that they reduce the risk of starvation during periods of extremely high turbidity and, hence, low light. During such periods, the coral energy budgets may become negative due to low rates of photosynthesis, despite rapid photoacclimation (Anthony et al. 2004). Although rates of heterotrophy increase with particle abundance (Ferrier-Pages et al. 1998), heterotrophy cannot compensate for the decline in photosynthesis in turbid-water habitats deeper than a few metres (Anthony \& Fabricius 2000).

The key finding of this study is that inshore corals have 2- to 4 -fold larger lipid stores than offshore conspecifics, despite 2-fold higher turbidity levels, suggesting that high turbidity is not a universal indicator of poor coral health. Implications are that reported adverse effects of sedimentation and turbidity on reefs may be due to processes operating at the population or community level rather than at the physiological level. For example, high loads of particulate nutrients may stimulate growth of macroalgae (Schaffelke 1999), which compete strongly for space with some corals (e.g. Hughes 1994), and sedimentation may prevent larval recruitment (Gilmour 1999). Likely conse- quences of larger energy stores in certain coral species on coastal reefs is a shift in the fitness hierarchy among species. This may, in part, explain the dominance of Turbinaria mesenterina on inshore reefs in this study, and the generally lower coral species diversity often observed on coastal turbid-water reefs (Done 1982, McClanahan \& Obura 1997).

Acknowledgements. I thank T. Lemberget, P. Rheinlander, T. Prior and S. Connolly for technical assistance, and T. Hughes, D. Bellwood, S. Connolly and A. Grottoli for comments on the penultimate draft. Three reviewers improved the final manuscript. The study was funded by a Discovery Grant from the Australian Research Council (Grant No. A19933033). This paper is a contribution from the Centre for Coral Reef Biodiversity.

\section{LITERATURE CITED}

Anthony KRN (1999) Coral suspension feeding on fine particulate matter. J Exp Mar Biol Ecol 232:85-106

Anthony KRN (2000) Enhanced particle-feeding capacity of corals on turbid reefs (Great Barrier Reef, Australia). Coral Reefs 19:59-67

Anthony KRN, Fabricius KE (2000) Shifting roles of heterotrophy and autotrophy in coral energetics under varying turbidity. J Exp Mar Biol Ecol 252:221-253

Anthony KRN, Connolly SR, Willis BL (2002) Comparative analysis of tissue and skeletal growth in corals. Limnol Oceanogr 47:1417-1429

Anthony KRN, Ridd PV, Orpin A, Larcombe P, Lough JM (2004) Temporal variation in light availability in coastal benthic habitats: effects of clouds, turbidity and tides. Limnol Oceanogr 49:2201-2211

Babcock RC (1991) Comparative demography of three species of scleractinian corals using age- and size-dependent classifications. Ecol Monogr 61:225-244

Barnes DJ, Lough JM (1999) Porites growth characteristics in a changed environment: Misima Island, Papua New Guinea. Coral Reefs 18:213-218

Berkelmans R (2002) Time-integrated thermal bleaching thresholds of reefs and their variation on the Great Barrier Reef. Mar Ecol Prog Ser 229:73-82

Brown BE (1997) Disturbances to reefs in recent times. In: Birkeland C (ed) Life and death of coral reefs. Chapman \& Hall, New York, p 354-385

Bryant D, Burke L, McManus J, Spalding M (eds) (1998) Reefs at risk. World Resources Institute, Washington, DC

Crossland CJ (1987) In situ release of mucus and DOC-lipid from the coral Acropora variabilis and Stylophora pistillata. Coral Reefs 6:35-42

Done TJ (1982) Patterns in the distribution of coral communities across the central Great Barrier Reef. Coral Reefs 1: 95-107

Dubinsky Z, Jokiel PL (1994) Ratio of energy and nutrient fluxes regulates symbiosis between zooxanthellae and corals. Pac Sci 48:313-324

Edmunds P, Gates RD (2002) Normalizing physiological data for scleractinian corals. Coral Reefs 21:193-197

Ferrier-Pages C, Allemand D, Gattuso JP, Jaubert J, Rassoulzadegan R (1998) Microheterotrophy in the zooxanthellate coral Stylophora pistillata: effects of light and ciliate density. Limnol Oceanogr 43:1639-1648 
Furnas M, Mitchell A, Skuza M, Brodie J (2005) In the other $90 \%$ : phytoplankton responses to enhanced nutrient availability in the Great Barrier Reef lagoon. Mar Pollut Bull 51:253-265

Gilmour J (1999) Experimental investigation into the effects of suspended sediment on fertilisation, larval survival and settlement in a scleractinian coral. Mar Biol 135:451-462

Gnaiger E, Bitterlich G (1984) Proximate biochemical composition and calorific content calculated from elemental CHN analysis: a stochiometric concept. Oecologia 62:289-298

Grottoli AG, Rodrigues LJ, Juarez C (2004) Lipids and stable carbon isotopes in two species of Hawaiian corals, Porites compressa and Montipora verrucosa, following a bleaching event. Mar Biol 145:621-631

Harrison PL, Wallace CC (1990) Reproduction, dispersal, and recruitment of scleractinian corals. In: Dubinsky Z (ed) Coral reefs, Vol 25. Elsevier, Amsterdam, p 133-207

Harrison PL, Babcock RC, Bull GD, Oliver JK, Wallace CC, Willis BL (1984) Mass spawning in tropical reef corals. Science 223:1186-1189

Houlbrèque $F$, Tambutté $E$, Allemand $D$, Ferrier-Pagès $C$ (2005) Interactions between zooplankton feeding, photosynthesis and skeletal growth in the scleractinian coral Stylophora pistillata. J Exp Biol 207:1461-1469

Hughes TP (1994) Catastrophes, phase shifts, and large-scale degradation of a Caribbean coral reef. Science 165: 1547-1551

Hughes TP, Baird AH, Bellwood DR, Card M and 13 others (2003) Climate change, human impacts, and the resilience of coral reefs. Science 301:929-933

IPCC (Intergovernmental Panel on Climate Change) (2001) Climate change 2001: synthesis report. IPCC, Wembley

Leuzinger S, Anthony KRN, Willis BL (2003) Reproductive energy investment in corals: scaling with module size. Oecologia 136:524-531

Maltby L (1999) Studying stress: the importance of organismlevel responses. Ecol Appl 9:431-440

Editorial responsibility: Otto Kinne (Editor-in-Chief), Oldendorf/Luhe, Germany
Marsh JA (1970) Primary productivity of reef-building calcareous red algae. Ecology 51:255-263

McClanahan TR, Obura D (1997) Sedimentation effects on shallow coral communities in Kenya. J Exp Mar Biol Ecol 209:103-122

McCulloch M, Fallon S, Wyndham T, Hendy E, Lough J, Barnes D (2003) Coral record of increased sediment flux to the inner Great Barrier Reef since European settlement. Nature 421:727-730

Muscatine L (1990) The role of symbiotic algae in carbon and energy flux in reef corals. In: Dubinsky Z (ed) Ecosystems of the world: coral reefs, Vol 25. Elsevier, Amsterdam, p 75-87

Nisbet RM, Muller EB, Lika K, Kooijman SALM (2000) From molecules to ecosystems through energy budget models. J Anim Ecol 69:913-926

Patterson MR, Sebens KP, Olson RR (1991) In situ measurements of flow effects on primary production and dark respiration in reef corals. Limnol Oceanogr 35:936-948

Rogers CS (1990) Responses of coral reefs and reef organisms to sedimentation. Mar Ecol Prog Ser 62:185-202

Roman MR, Furnas MJ, Mullin MM (1990) Zooplankton abundance and grazing at Davies Reef, Great Barrier Reef, Australia. Mar Biol 105:73-82

Rosenfeld M, Bresler V, Abelson A (1999) Sediment as a possible source of food for corals. Ecol Lett 2:345-348

Schaffelke B (1999) Particulate organic matter as an alternative nutrient source for tropical Sargassum species (Fucales, Phaeophyceae). J Phycol 35:1150-1157

Sebens KP, Grace SP, Helmuth B, Maney EJ, Miles JS (1998) Water flow and prey capture by three scleractinian corals, Madracis mirabilis, Montastrea cavernosa and Porites porites, in a field enclosure. Mar Biol 131:347-360

Veron JEN (1986) Corals of Australia and the Indo-Pacific. University of Hawaii Press, Honolulu, HI

Wilkinson CR (ed) (2002) Status of coral reefs of the world: 2002. Australian Institute of Marine Science, Townsville

Submitted: November 3, 2005; Accepted: January 27, 2006 Proofs received from author(s): July 22, 2006 